\title{
Hydrodynamic Considerations VI: Temporary Shunting for Intraventricular Hemorrhage: Observational Study of Two Treatment Variants
}

\section{Considerações hidrodinâmicas VI: Drenagem temporária nas hemorragias intraventriculares. Estudo observacional de duas variantes de tratamento}

\author{
Victor Beneditti Guimarães ${ }^{1}$ Felipe Henrique Muniz ${ }^{1}$ Jakeline Flávia Sertório Santos ${ }^{1}$ \\ Raphael Bertani $^{1}$ Ruy Monteiro ${ }^{2}$ Angelo Luiz Maset ${ }^{3}$ Dionei Moraes ${ }^{4}$ \\ ${ }^{1}$ Faculdade de Medicina de São José do Rio Preto, São José do Rio \\ Address for correspondence Angelo Luiz Maset, MD, Av Carlos de \\ Preto, SP, Brazil \\ 2 Department of Neurosurgery, Hospital Municipal Miguel Couto, Rio \\ Arnaldo Silva, 360, Village Sta. Helena, São Jose do Rio Preto, SP, \\ de Janeiro, RJ, Brazil \\ ${ }^{3}$ Department of Neurosurgery, Hospital de Base de São José do Rio \\ Preto, São José do Rio Preto, SP, Brazil \\ ${ }^{4}$ Department of Neurosurgery, Faculdade de Medicina de São José do \\ Rio Preto, São José do Rio Preto, SP, Brazil, \\ Arq Bras Neurocir 2021;40(1):44-50.
}

\section{Abstract \\ Keywords \\ - external ventricular drainage \\ - intraventricular hemorrhage \\ - intracerebral hemorrhage \\ - intraventricular catheter}

Introduction Patients who have external ventricular drainage (EVD) inserted are prone to many risks and complications. Intraventricular hemorrhage (IVH) is a frequent and life-threatening complication for spontaneous intracerebral hemorrhage (ICH) and results in an increased morbidity and mortality for those patients. An EVD insertion is a frequent surgical procedure for those with IVH. However, it is also known that IVH patients have a much higher rate of ventricular catheter occlusion. We hypothesize that blood clots have a predominant participation as a pathophysiological mechanism for EVD occlusion, and that a different and more appropriate catheter design might decrease the occlusion rate occurring during the utilization of EVDs on patients with IVH and, therefore, reduce implantation time.

Methods The electronic data sheets of 30 patients with spontaneous IVH from March 2014 until April 2015 were evaluated. Two concepts in catheter design were evaluated: A group of 15 patients with a conventional type of catheter inserted was identified as Group C (conventional). A group of 15 patients with a new design of catheter inserted was identified as Group $\mathrm{H}$ (hemorrhagic). Both groups were compared regarding survival end parameters, outcomes, days spent in intensive care units (ICUs) and time spent with EVDs implanted.

Results Hospitalization at the ICU was statistically significantly reduced for Group $\mathrm{H}$ compared with Group C. There was no significant difference among the hospitalization received

March 30, 2020

accepted

August 5, 2020

published online

January 18, 2021
DOI https://doi.org/ $10.1055 / \mathrm{s}-0040-1718428$ ISSN 0103-5355.

\footnotetext{
(C) 2021. Sociedade Brasileira de Neurocirurgia. All rights reserved. This is an open access article published by Thieme under the terms of the Creative Commons Attribution-NonDerivative-NonCommercial-License, permitting copying and reproduction so long as the original work is given appropriate credit. Contents may not be used for commercial purposes, or adapted, remixed, transformed or built upon. (https://creativecommons.org/ licenses/by-nc-nd/4.0/) Thieme Revinter Publicações Ltda., Rua do Matoso 170, Rio de Janeiro, RJ, CEP 20270-135, Brazil
} 


\section{Resumo}

\section{Palavras-chave}

- drenagem ventricular externa

- hemorragia intraventricular

- hemorragia intracerebral

- cateter intraventricular days between both groups. There was no statistical difference either for acute hydrocephalus or death rate. External ventricular drainage implantation days were significantly reduced for Group H related to Group C.

Conclusion The results of the present study points to the fact that, although apparently the new catheter design did not change some secondary complications such as hydrocephalus and hospitalization rate, it seems that a better or specifically designed catheter for IVH purposes might lead to less ICU hospitalization days and EVD implantation days, two factors that have economic impact on healthcare due to the reduction of hospitalization costs and reduced incidence of related complications. The information obtained by this preliminary study should be grounded by a larger, more detailed and prospective evaluation; if these preliminary data are maintained, the new design should be considered for IVH associated EVDs insertions.

Pacientes que utilizam drenagem ventricular externa (DVE) estão sujeitos a muitos riscos e complicações. A hemorragia intraventricular (IVH) é uma complicação frequente na hemorragia intracerebral espontânea (HIC) e resulta em um aumento da morbidade e mortalidade para esses pacientes. A inserção de DVE é um procedimento cirúrgico frequente para pessoas com HIV. No entanto, também se sabe que os pacientes com HIV têm uma taxa muito maior de oclusão do cateter ventricular. Nossa hipótese é que os coágulos sanguíneos têm uma participação predominante como um mecanismo fisiopatológico para a oclusão da DVE, e que um design de cateter diferente e mais apropriado pode diminuir a taxa de oclusão que ocorre durante a utilização de DVEs em pacientes com IVH e, portanto, reduzir o tempo de implantação.

Métodos Foram avaliadas as planilhas eletrônicas de 30 pacientes com HIV espontânea de março de 2014 a abril de 2015. Dois conceitos no desenho do cateter foram avaliados: Um grupo de 15 pacientes com um tipo convencional de cateter inserido foi identificado como Grupo C (convencional). Um grupo de 15 pacientes com um novo desenho de cateter inserido foi identificado como Grupo H (hemorrágico). Ambos os grupos foram comparados em relação aos parâmetros finais de sobrevivência, resultados, dias passados em unidades de terapia intensiva (UTI) e tempo gasto com EVDs implantados.

Resultados A internação na UTI foi estatisticamente reduzida para o Grupo H em comparação com o Grupo C. Não houve diferença significativa entre os dias de internação entre os dois grupos. Não houve diferença estatística para hidrocefalia aguda ou taxa de mortalidade. Os dias de implantação de drenagem ventricular externa foram significativamente reduzidos para o Grupo $\mathrm{H}$ em relação ao Grupo $\mathrm{C}$.

Conclusão Os resultados do presente estudo apontam para o fato de que, embora aparentemente o novo desenho do cateter não tenha alterado algumas complicações secundárias, como hidrocefalia e taxa de hospitalização, parece que uma melhor ou específica.

\section{Introduction}

Although intracerebral hemorrhage (ICH) estimates are between 10 and $15 \%$ of all strokes, ${ }^{1,2}$ it is related to worse prognosis compared with any other isolated stroke event, especially in the presence of intraventricular hemorrhage (IVH). ${ }^{1,3,4}$ Morbidity and mortality rates are in between 50 and $80 \%{ }^{2,5}$ When IVH occurs, blood drawn into the cerebral ventricles and/or cisterns often causes, as an immediate result, a partial or total blockage of the cerebrospinal fluid
(CSF) pathways, immunological deficiency, ${ }^{4}$ higher rates of infection, ${ }^{2,4}$ acute hydrocephalus and intracranial hypertension, ${ }^{5,6}$ possibly requiring surgical treatment in an urgent basis. Ultimately, IVH is a life-threatening condition, which increases morbidity and mortality when associated with ICH. Surgical management consider external ventricular drainage (EVD) alone, bilateral EVDs, fibrinolytics + EVD, endoscopic surgery, endoscopic surgery + EVD, among others. ${ }^{5}$

However, it is also known that IVH patients have a much higher rate of ventricular catheter occlusion. We hypothesize 
that blood clots have a predominant participation as a pathophysiological mechanism for EVD occlusion, and that a different and more appropriate catheter design might decrease the occlusion rate occurring during the utilization of EVDs in patients with IVH and, therefore, reduce implantation time.

\section{Material and Methods}

The present study was approved by the Fundação Faculdade Regional de Medicina (FUNFARME, in the Portuguese acronym) Ethics Committee. It is an observational retrospective study done with 30 nontraumatic ICH patients with extension to the ventricular cavities (IVH) during the period of March $1^{\text {st }} 2014$ until April $30^{\text {th }} 2015$ at FUNFARME, Sao José do Rio Preto, state of São Paulo, Brazil. In the present preliminary study, we compared two different concepts of ventricular catheters. At first, we searched for an EVD model that follows the recommendations of Tronnier et al. ${ }^{7}$ for an adequate EVD to minimize mechanical failures and infections. There were a total number of 30 patients, 15 patients for each conceptual group. The first concept was denominated as $C$ (conventional, because it is the conventional catheter offered in drainage sets for this manufacturer). It is a $23 \mathrm{~cm}$ length silicone tubing, closed tip, 1,7 I.D. $x$ 3,0 mm O.D., with 12 oblong holes $1 \times 2 \mathrm{~mm}$ each, the more distant hole being $17 \mathrm{~mm}$ distant from the catheter tip. (-Fig. 1A). The model C product has a Brazilian ANVISA registration \# 10175060016. The second group was identified as H (hemorrhage), and it has an ANVISA registration \# 10175060037 , both made commercially available by the same manufacturer. Group H patients (Type H catheter, - Fig. 1B) included a larger bore, open end tip, 2,6 I.D. x 4,0 m O.D, four oblong and bigger sized lateral holes, the more distant hole being $15 \mathrm{~mm}$ distant from the catheter tip. The type $\mathrm{H}$ catheter was specifically designed for IVH, in an attempt to decrease the incidence of blockage caused by particles in the CSF that regularly would clog the small orifices, the catheter lumen, and/or the connector site into the EVD set in conventional EVDs and, consequently, would require surgical revision or manual unclogging procedures at bedside leading to either increased infection rates, increased number of ICU hospitalization days, increased number of hospitalization days, acute hydrocephalus (defined as hydrocephalus while at the hospital), or increased number of EVD implantation days. ${ }^{6}$

The objective of the present study was to verify the efficacy of two different external ventricular drainage catheter concepts regarding: 1 . ICU hospitalization days; 2 . EVD implantation days, and 3. Occurrence of acute hydrocephalus. Acute hydrocephalus was defined as hydrocephalus while the patient was hospitalized.

Inclusion criteria: spontaneous intracranial hemorrhage seen on initial computed tomography (CT) scan at the emergency room (ER), Glasgow coma score $(\mathrm{GCS})^{8}<9$ at admission after patient resuscitation, $\mathrm{ICH} \leq 3$ (ICH score), ${ }^{9}$ to whom EVD insertion was clinically indicated. The target ventricle for Group $\mathrm{H}$ was always the most blood compromised ventricle. For Group C, we followed the literature, inserting them in the least compromised ventricle. The reasoning for that was to make sure that a larger bore catheter would unequivocally have some effect on drainage of liquified blood.

Exclusion criteria: abnormal coagulation patterns at initial blood sample, initial utilization of antifibrinolytics, ICH score $>3$ or GCS $>9$ at resuscitation
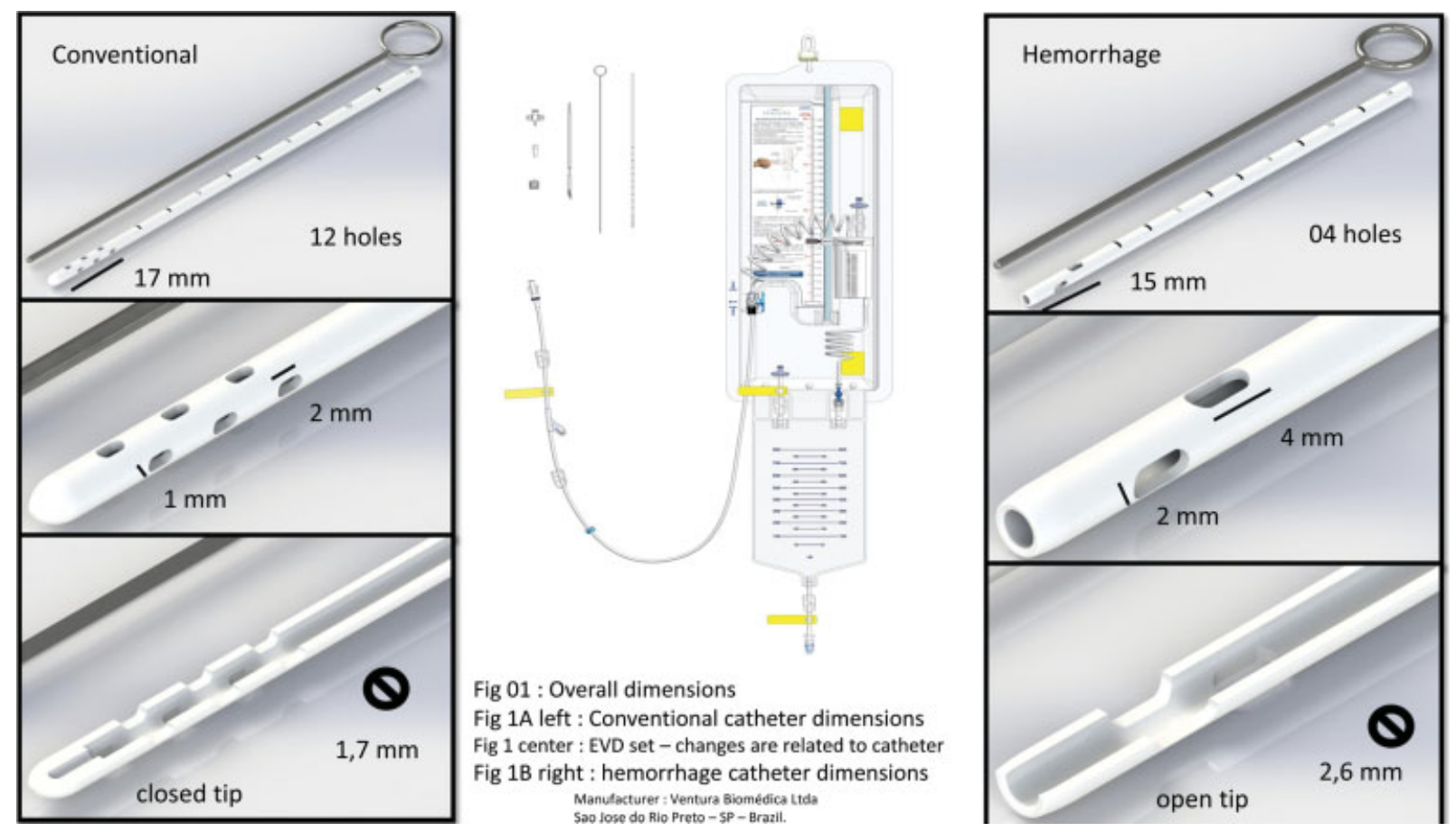

Fig. 1 Overall dimensions. (A) Left: Conventional catheter dimensions. (B) Center: EVD set - changes are related to catheter. (C) Right: hemorrhage catheter dimensions. 


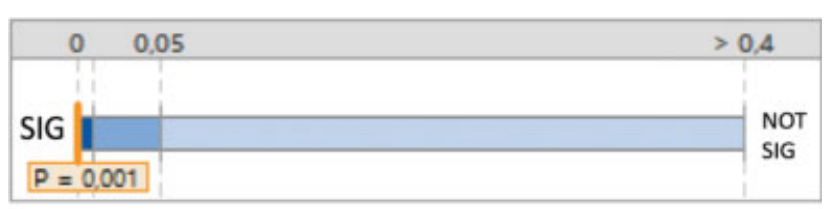

The average days at ICU in Group H was significantly lower than the average at group $C(P<0,01)$.

Fig. 2 (A) Intensive care unit average days - comparison between Group $\mathrm{H}$ and Group C. Intensive care unit average days for Group H was statistically significant smaller when compared to Group $C$ at $\mathrm{p}=0.001$. (B) Ventricular catheter implantation days. Ventricular catheter implantation days for Group $\mathrm{H}$ was statistically significant compared with Group C.

\section{Procedures}

After approval by the Ethics Committee, electronic files were reviewed and the patients were identified. Collected data were age, pupils at admission, GCS score, pre-existent pathologies, and type of catheter used. It was possible to select 30 patients, 15 patients for each group. Both groups were then compared according to the parameters described above.

Table II II-A Total Hospitalization days

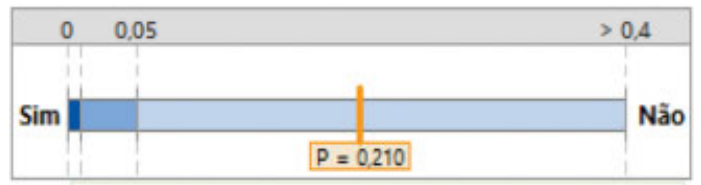

Average total hospitalization days isn't statistically significant for groups $\mathrm{H}$ and $\mathrm{C}$

\section{II-B Hydrocephalus}

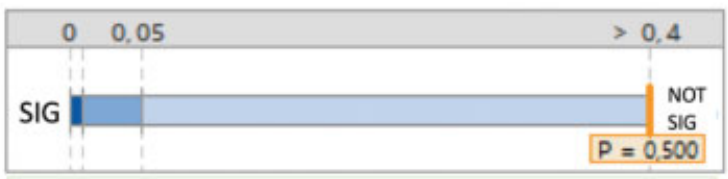

Hydrocephalus cases aren't statistically significant for groups $\mathrm{H}$ and $\mathrm{C}$

\section{II-C Deaths}

\begin{tabular}{|l|l|l|l|}
\hline & 0 & 0.05 & $>0,4$ \\
\hline & & & \\
SIG & & & NOT \\
& & $P=0.225$ & \\
\hline
\end{tabular}

Death cases in Group H wasn't statistically significant lower than in Group C.

Fig. 3 (A) Total Hospitalization days. Average total hospitalization days isn't statistically significant for groups $\mathrm{H}$ and C. (B) Hydrocephalus. Hydrocephalus cases aren't statistically significant for groups $\mathrm{H}$ and C. (C) Deaths. Death cases in Group H wasn't statistically significantly lower than in Group C.

\section{Data Analysis}

We used parametric tests (t-student test for ordinary variables and the chi-squared test for nominal variables) and a level of significance of $p \leq 0.05$.

\section{Results}

The average ICU hospitalization days for group $\mathrm{H}$ was $14.4 \pm 8.4$ standard deviation (SD) versus $24.4 \pm 7.9$ days for group C, a mean difference of 9.8 ICU hospitalization days. This difference was statistically significant $(p=0.001$ - Fig. 2A). This result made us review the total hospitalization days, which was $21.4 \pm 13.0$ days for group $\mathrm{H}$ versus $25.94 \pm 16.9$ days for group $C$. This difference still was not statistically significant ( $\mathbf{F i g} \cdot \mathbf{3 A} p=0.21$ ). The number of patients who developed hydrocephalus between Groups $\mathrm{H}$ and $C$ respectively were 4 and 5 , percentual of 26.67 and 33.33\% respectively, with no statistical significance (-Fig. 2B $p=0.5$ ). Finally, the number of patients who died between Groups $\mathrm{H}$ and $\mathrm{C}$ were 8 and 11, percentual of $53.3 \%$ and $73.33 \%$ respectively, again with no statistical significance ( - Fig. 3C $p=0.225$ ). The average implanted catheter days between Group $H$ and $C$ was $7.7 \pm 3.3$ versus $11.2 \pm 2.93$ days for group C, a mean difference of 3.5 days favoring Group $\mathrm{H}$. This difference was statistically significant at $p=0.003$ (-Fig. 2B).

\section{Discussion}

It is reported that ICH accounts for between 10 and 30 incidents / 100.000 habitants, with an estimate of $\sim 2$ million strokes per year. ${ }^{2}$ Intracranial hemorrhage with or without IVH accounts for $15 \%$ of all strokes, and subarachnoid hemorrhage (SAH) accounts for $5 \%$ of all strokes. The prognosis for ICH is disproportional and devastating, reaching between 35 and $50 \%$ of mortality for 30 days, being half of them during the first 2 days; it is even higher when associated with IVH, reaching between 50 and $80 \%$ of mortality for 30 days. Intraventricular hemorrhage occurs in between $5-10 \%$ of SAH patients and in up to $40 \%$ of ICH patients. Only $38 \%$ of ICH patients survive for 1 year. Therefore, massive IVHs require aggressive and rapid management to decrease intracranial hypertension, mainly due to acute hydrocephalus. The immediate control of intracranial pressure (ICP) by external ventricular drainage is a salvage procedure; the amount of intraventricular blood is a strong negative prognostic predictor on outcome. ${ }^{1,3,4}$ External ventricular drainages are the most common surgical procedure for IVH, and they are indicated for the control of intracranial pressure as the blood and blood clots compromise acutely the CSF circulation. External ventricular drainages are hydraulic devices that work against a positive pressure, regulated by the positioning aside the patient at the ICU. ${ }^{10}$ It is known that EVDs do not decrease morbidity and mortality, but catheter occlusions do increase de risk of infection, hydrocephalus and neurological deterioration. Yet, EVD insertions are at large the most common choice of treatment, ${ }^{5,11}$ and the search for additional and/or concomitant treatments is constant. 
Catheters are usually inserted in the cleanest lateral ventricle. As mentioned in the Methods section, our target ventricle for the Group $\mathrm{H}$ was the most blood compromised ventricle. The whole of blood into the ventricles and the catheter design has been a matter of discussion either on permanent shunts or EVDs. ${ }^{6,11,12}$ Thomale et al $^{12}$ replaced a regular catheter design with 16 holes by a new design with 4 or 6 holes only, both with a closed end, maintaining the same diameter and distance among holes for all of them, but the maximum distance from the tip was $6,4 \mathrm{~mm}$ as compared with $15,4 \mathrm{~mm}$ from the conventional catheter. The 6 -hole catheter was implanted in 55 hydrocephalic patients with a mean follow-up period of $15 \pm 9$ months. A total of 12 catheters were explanted, revealing an overall survival proportion of $77.4 \%$. He concluded that "fewer amounts of perforations in the catheters with equal flow features might decrease this risk when catheters can be implanted with adequate precision. However, EVDs work in a different environment as compared to shunts, are short term implants, and therefore ventricular catheters face different CSF conditions, since those patients frequently are submitted to increased concentrations of proteins, debris and blood."
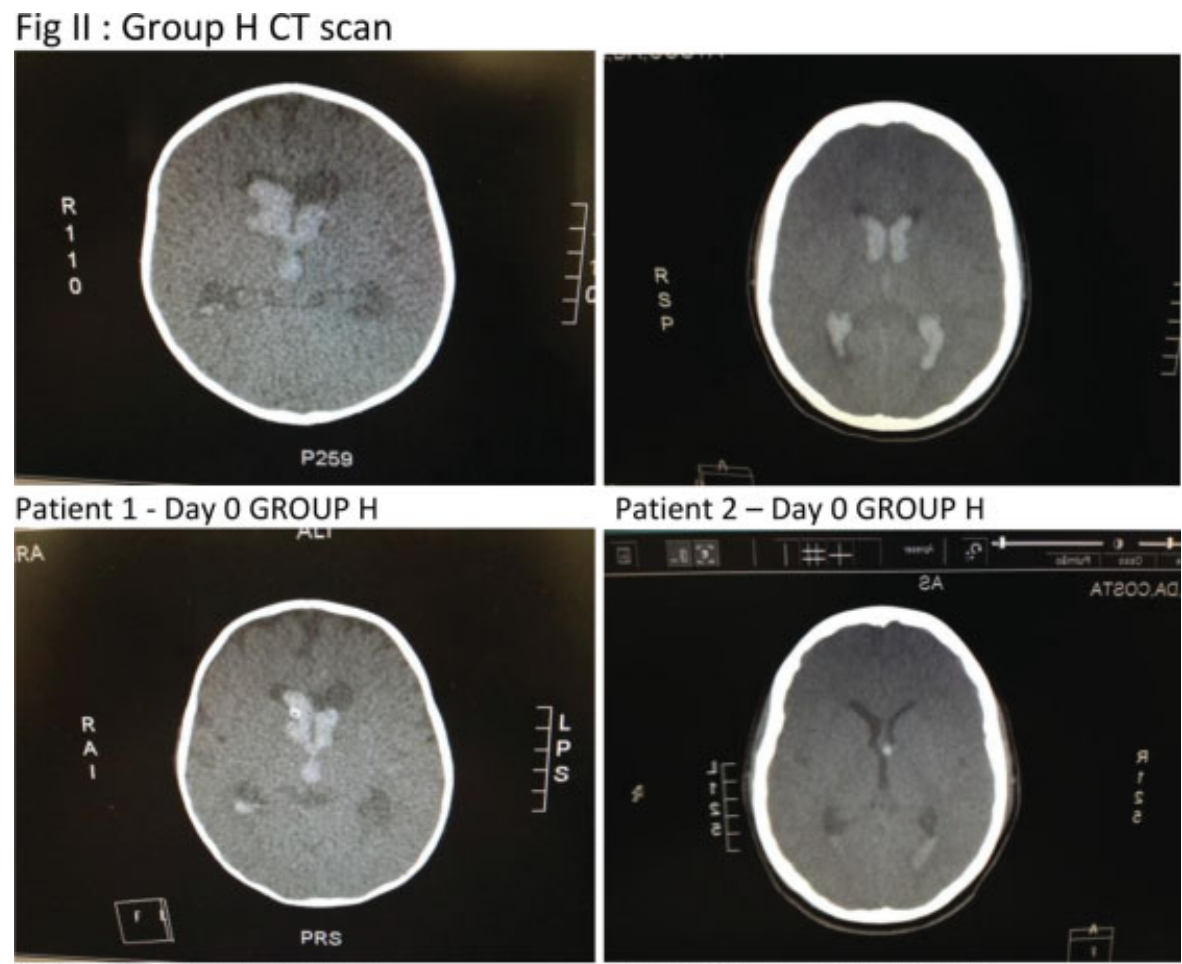

Patient 2 - Day 0 GROUP H
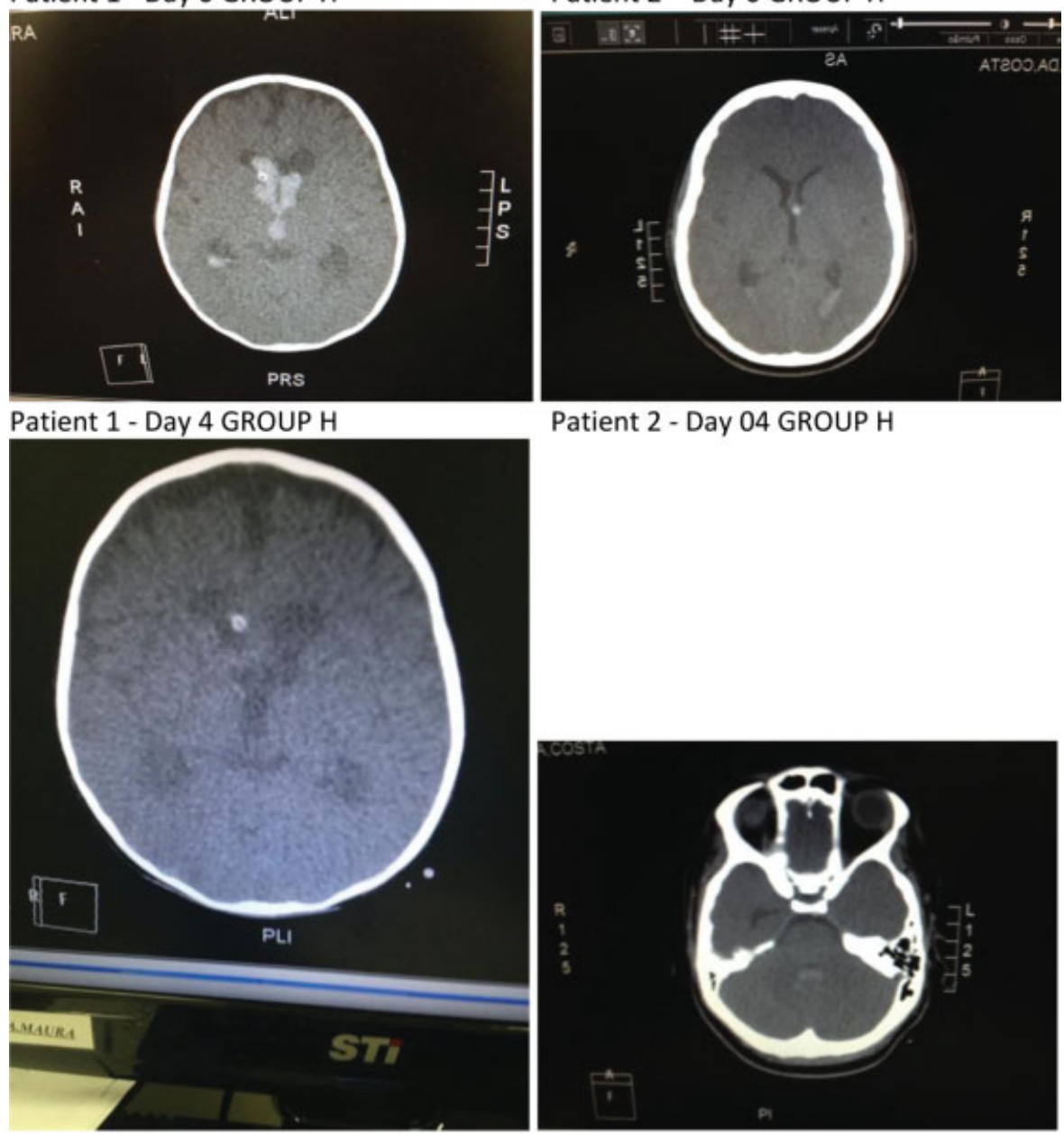

Patient 2 - Day 04 GROUP H

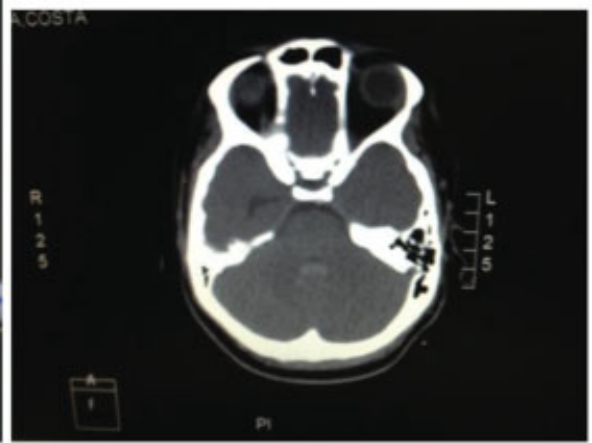

Patient 1 - Day 11 GROUP H

Patient 2 - Day 4 GROUP H

Fig. 4 Group H computed tomography scan. (A) Patient 1 - Day 0 GROUP H. (B) Patient 2-Day 0 GROUP H. (C) Patient 1 - Day 4 GROUP H. (D) Patient 2 - Day 04 GROUP H. (E) Patient 1-Day 11 GROUP H. (F) Patient 2-Day 4 GROUP H. 
Tronnier et al, ${ }^{7}$ in 1991, evaluated 12 commercially available sets for drainage of CSF for several mechanical aspects. "All systems showed considerable deficiencies in their reliability and handling. None of them can be recommended without certain restrictions and they should all be revised." Thus, they suggested changes in the catheter hole design, mentioning specifically that in "75\% of our patients the CSF is hemorrhagic or very viscous and the risk of catheter occlusion is high." Length markers, type of catheter fixation, surface properties, one-way valve, orthograde and retrograde flows, fixation and adjustment of the drip chamber, system ventilation and collection bag also were all matter of evaluation and further suggestions. The choice of the EVD for the present work was based on those presumptions, and we selected the one that included most of those attributes. We did not implant two catheters simultaneously in either group. Basaldella et al ${ }^{13}$ recommended that "tetra-ventricular blood inundation should be managed using bilateral ventricular catheters, which frequently become obstructed by blood clots and need to stay in place for a longer period for blood washout." Naff et $\mathrm{al}^{14}$ clearly demonstrated that the percentage of clot clearance is $10.8 \%$ per day and is independent from the initial clot volume, patient age and gender, type of underlying hemorrhage, and use of EVD. Another approach is endoscopic surgery, sucking the blood clots and apparently improving CSF circulation, although EVDs are still inserted after endoscopic surgery. Basaldella ${ }^{13}$ compared retrospectively EVD alone (group $B ; n=48$ ) versus endoscopic surgery + EVD (group A, $n=48$ ). They all had acute hydrocephalus before obstruction, $3^{\text {rd }}$ and $4^{\text {th }}$ ventricles obstruction, similar average Glasgow Coma Scale (GCS), similar average GRAEB $^{15}$ scale. His conclusions, among others, were "the endoscopic procedure resulted in adequate clot removal. Mean GRAEB score changed from 9.5 to 3.8; endoscopic aspiration had an EVD in place for 0.18 days fewer than patients treated with an EVD alone. Neuroendoscopy plus external drainage reduces shunting rates by $34 \%$ when compared with external drainage alone. However, and as seen in that same work, ${ }^{13}$ patients end up reaching the same modified Rankin scale ${ }^{16}$ and, on average, the EVDs on patients submitted to endoscopy remained only 0.18 days less. Although endoscopy remains elusive regarding several aspects, for sure the ventricular system is cleaned much faster and there is less exposition of the subarachnoid vessels to the products resulting from degradation of the blood. Tuhrim et $\mathrm{al}^{17}$ did a prospective study to determine the prognostic significance and pathophysiologic implications of intraventricular extension of ICH and showed that 30-day mortality was much higher in patients with IVH. There was a direct correlation between IVH volume and poor outcome, and this correlation persisted when comparing for the presence or absence of hydrocephalus and size of associated ICH, thus establishing IVH volume as an independent prognostic factor of poor outcome, independent of the volume of $\mathrm{ICH}^{17}$ Another technique is the use of fibrinolytics agents to dissolve clots. This technique tries to expedite the ventricular blood clots and decrease mortality and morbidity. However, results from Randomised, multicentre, multiregion, placebo- controled trial (CLEAR III) ${ }^{18}$ did not get the expected results; irrigation with alteplase did not substantially improve functional outcomes at the mRS3 cutoff compared with irrigation with saline. Alteplase demonstrated to be a safe procedure, though. In the present preliminary work, we utilized a recent EVD commercially available in Brazil for hemorrhage. Since the proposal of the EVD made sense to us, we decided to use 15 EVDs for an initial assessment. Along with the utilization, we observed a striking difference between both types of catheter regarding drainage capability. The elimination of clots that were unthinkable on a regular EVD was a common event for the hemorrhage type, and the occlusion rate was small. The CSF became cleaner faster with the hemorrhage

\section{Fig III : Example of Conventional group.}
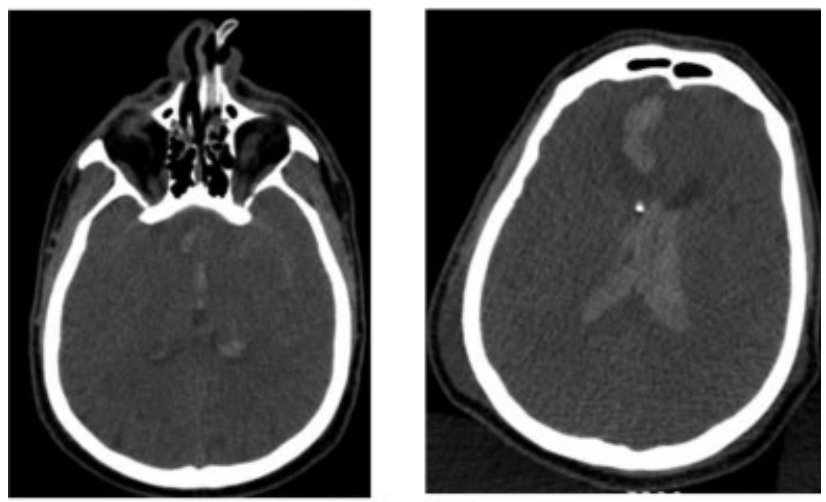

Patient 1 Day 0 Group C

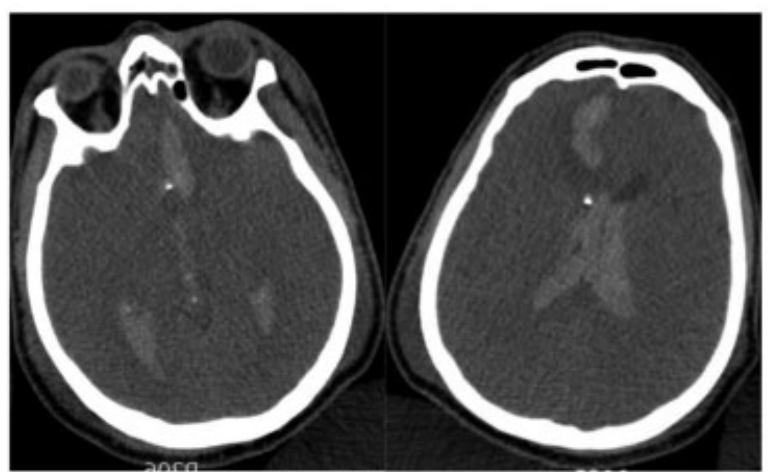

Patient 1 - Day 6 Group C
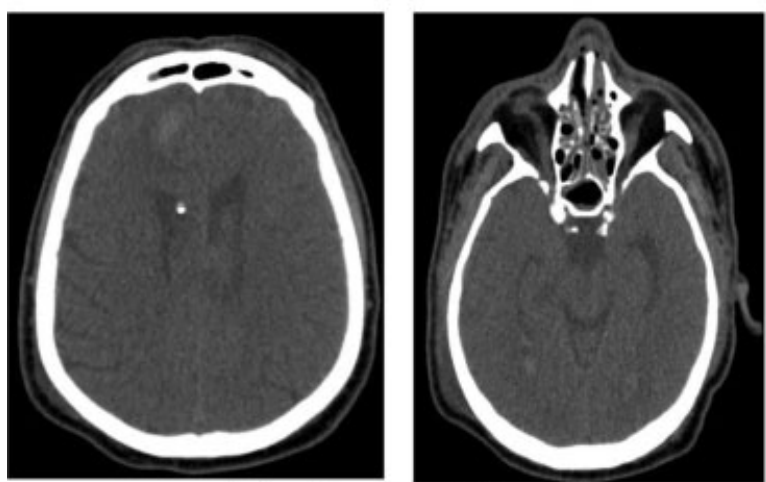

Patient 1 - Day 16 Group C

Fig. 5 Example of Conventional group. (A) Patient 1 Day 0 Group C. (B) Patient 1-Day 6 Group C. (C) Patient 1-Day 16 Group C. 
type of catheter. The chosen EVD system has some important details that avoid mechanical clogging or occlusion for several reasons. A common weakness in EVD refers to the disparity of the lumen of the male connector to insert into the ventricular catheter and the catheter itself. This EVD has the lumen of the ventricular catheter as the smallest diameter along the whole EVD tubing set. Another advantage is the horizontal fixation tab as part of the body of the connector. There is no chance of the ventricular catheter to slip through the fixation tab and allow vertical slides by the catheter. As a preliminary work, there was no randomization regarding imaging dates from the ictus day. Computed tomographies were made according to the necessity of each patient ( - Fig. 4 for Group H and - Fig. 5 for Group C). Although with a small number of patients, the optimistic results regarding ICU days and ventricular catheter implantation days between both types of catheter led us to maintain the initial target of 15 patients and organize a trial in such a way that we could collect a larger number of patients taking into consideration several other factors. At least for those 15 patients, we did not observe any additional adverse events for using a larger bore ventricular catheter.

\section{Conclusion}

Despite the small number of patients, some results seemed to favor the type $\mathrm{H}$ ventricular catheter and encouraged us to proceed with a trial. The reduced number of ICU days and ventricular catheter implantation time favoring Group $\mathrm{H}$ reached statistical significance at $p<0.01$. Considering the daily cost for hospitalization in our country, the impact on the daily ICU costs due to use of Type $\mathrm{H}$ catheters may represent an interesting tool for cost reduction and maybe to avoid collateral damage to the patient. These results are motivating for a prospective, more detailed study with a larger number of patients.

\section{Conflict of Interests}

The authors have no conflict of interests to declare. The Doctor Angelo Maset declares that he is CEO and owner of the company Ventura Biomédica.

\section{References}

1 González-Pérez A, Gaist D, Wallander MA, McFeat G, GarcíaRodríguez LA. Mortality after hemorrhagic stroke: data from general practice (The Health Improvement Network). Neurology 2013;81(06):559-565

2 Ministério da Saúde Secretaria de Atenção à Saúde, Departamento de atenção especializada, Coordenação geral de média e alta complexidade, Coordenação geral de atenção hospitalar. 2013.
Manual de Rotinas para atenção ao AVC. Ministério da Saúde, Secretaria de Atenção à Saúde, Departamento de atenção especializada. Brasília: Editora do Ministério da Saúde, 2013. 50p.

3 Gaberel T, Magheru C, Parienti JJ, Huttner HB, Vivien D, Emery E. Intraventricular fibrinolysis versus external ventricular drainage alone in intraventricular hemorrhage: a meta-analysis. Stroke 2011;42(10):2776-2781

4 Sykora M, Diedler J, Poli S, et al. Autonomic shift and increased susceptibility to infections after acute intracerebral hemorrhage. Stroke 2011;42(05):1218-1223

5 Hughes JD, Puffer R, Rabinstein AA. Risk factors for hydrocephalus requiring external ventricular drainage in patients with intraventricular hemorrhage. J Neurosurg 2015;123(06):1439-1446

6 Wang K, Du HG, Yin LC, He M, Hao BL, Chen L. Which side of lateral ventricles to choose during external ventricular drainage in patients with intraventricular hemorrhage: ipsilateral or contralateral? J Surg Res 2013;183(02):720-725

7 Tronnier V, Aschoff A, Hund E, Hampl J, Kunze S. Commercial external ventricular drainage sets: unsolved safety and handling problems. Acta Neurochir (Wien) 1991;110(1-2):49-56

8 Teasdale G, Jennett B. Assessment of coma and impaired consciousness. A practical scale. Lancet 1974;2(7872):81-84

9 Hemphill JC III, Bonovich DC, Besmertis L, Manley GT, Johnston SC. The ICH score: a simple, reliable grading scale for intracerebral hemorrhage. Stroke 2001;32(04):891-897

10 Maset AL, Bim C, Camilo JR, Mansur SS, Vieira ER Caracterização hidrodinâmica de dispositivos para drenagem externa de líquido cefalorraquidiano. CIBEM 10, Porto, Portugal, 2011

11 Dey M, Jaffe J, Stadnik A, Awad IA. External ventricular drainage for intraventricular hemorrhage. Curr Neurol Neurosci Rep 2012; 12(01):24-33

12 Thomale UW, Hosch $\mathrm{H}$, Koch A, et al. Perforation holes in ventricular catheters-is less more? Childs Nerv Syst 2010;26 (06):781-789

13 Basaldella L, Marton E, Fiorindi A, Scarpa B, Badreddine H, Longatti P. External ventricular drainage alone versus endoscopic surgery for severe intraventricular hemorrhage: a comparative retrospective analysis on outcome and shunt dependency. Neurosurg Focus 2012;32(04):E4

14 Naff NJ, Hanley DF, Keyl PM, et al. Intraventricular thrombolysis speeds blood clot resolution: results of a pilot, prospective, randomized, double-blind, controlled trial. Neurosurgery 2004; 54(03):577-583, discussion 583-584

15 Graeb DA, Robertson WD, Lapointe JS, Nugent RA, Harrison PB. Computed tomographic diagnosis of intraventricular hemorrhage. Etiology and prognosis. Radiology 1982;143(01):91-96

16 van Swieten JC, Koudstaal PJ, Visser MC, Schouten HJA, van Gijn J. Interobserver agreement for the assessment of handicap in stroke patients. Stroke 1988;19(05):604-607

17 Tuhrim S, Horowitz DR, Sacher M, Godbold JH. Volume of ventricular blood is an important determinant of outcome in supratentorial intracerebral hemorrhage. Crit Care Med 1999;27(03): 617-621

18 Hanley DF, Lane K, McBee NCLEAR III Investigators. et al. Thrombolytic removal of intraventricular haemorrhage in treatment of severe stroke: results of the randomised, multicentre, multiregion, placebo-controlled CLEAR III trial. Lancet 2017;389 (10069):603-611 